8. Hayakawa, K. End use quality of waxy wheat flour in various grain-based foods [Текст] / К. Hayakawa [и др.] // Cereal

chemistry. - 2004. - Vol. 81, №5. - P. 666-672.
Hung, P. V. Dough and bread qualities of flours with whole waxy wheat flour substitution [Teкcr] / P. V. Hung, T.
Meeda N. Morita // Food Research International - 2007.-Vol. 40, No1_- P. 273-279. 作 // Journal of Cereal Science. - 2009. - Vol. 50, №3. - P. 364-369.

1. Рибалка, О. І. У цивілізованому світі добре розуміють харчову цінність натуральних продуктів здорового харчу-
вання [Текст] / О. І. Рибалка // Хлібопекарська і кондитерська промисловість України. - 2011 - №3 - С. 7-16. вання [Текст] / О. І. Рибалка // Хлібопекарська 1 кондитерська промисловість Украӥни. - 2011. - №3. - С. 7-16. показатели качества зерна [Текст] / И. Г. Топораш [и др.] // Зернові продукти і комбікорми. - 2012. - №2. - С. 30-

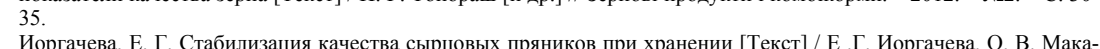
Иоргачева, Е. Г. Стабилизация качества сырцовых пряников при хранении [Текст] / Е.Г. Иоргачева, О. В. Мака-
рова, Е. В. Хвостенко // Восточно-европейский журнал передовых технологий. - 2014. - № 2/12 (68) ч. 2. - С. . дукти і комбікорми. - 2013. - №3. - С. 23-27. Іоргачова, К. Г. Визначення технологічних властивостей борошна 3 безамілозної пшениці за станом вуглеводно-
амілазного комплеску [Текст] / К.Г. Іоргачова, О.В. Макарова., К.В. Хвостенко, О.І. Рибалка // Харчова наука і

16. Сборник рецептур мучных кондитерских и булочных изделий [Текст] - С-Пб: Профи, 2010. - С. 644.

8. Лебеденко, Т. Є. Технологія хлібопекарського виробництва. Практикум [Текст] / Т.Є. Лебеденко, Г.Ф. Пшенишнюк, Н.Ю. Соколова - О: Освіта України, 2014. - 392 с.

\section{УДК [006.063:504.06]:[631.147:664]:005.934}

\section{ЕКОЛОГІЧНЕ МАРКУВАННЯ ОРГАНІЧНИХ}

\section{М'ЯСНИХ ПРОДУКТІВ}

Крусір Г.В. доктор технічних наук, професор* E-mail: krussir_65@mail.ru

Короленко Л.І. кандидат хімічних наук, доцент* Кіріяк А.В. кандидат хімічних наук, доцент E-mail: sonitak@meta.ua
Чернишова 0.0. аспірант Чернишова О.О. аспірант
E-mail: mobilochka_17@mail.ru *кафедра екології харчових продуктів і виробництв Одеська національна академія харчових технологій
вул. Канатна, 112, м. Одеса, Україна, 65039

Анотація. Основні питання статті присвячено екологічному маркуванню органічної м'ясної продукції. У той час, коли відносини між Украӥною та країнами Європейського Союзу стали більш інтенсивними, сегмент органічних дуктів сільського господарства, невід'емною частиною яких є енергооптимізація та курс на високу якість та безпечність харчової продукції, дозволять Україні зайняти у майбутньому лідируюче місце серед виробників органічого,
Враховуючи контроль за такою продукцією зі сторони іноземних органів сертифікації, для забезпечення відповідності продукції до вказаних характеристик, виникла потреба в об̄'єктивних експериментальних методах визначення органічності товарів. У статті розглядасться один з найбільш важливих етапів процедури отримання знаку екологічного маркування органічної продукції - розробка методики оцінки органічності. Значна увага приділяеться стадії розробки критеріїв методики та методи іх визначення для проведення експертизи, метою якої є оцінка органічні м'ясних продудосліджуваних зразків м'ясної продукшії було використано свинину різних виробників. Перший зразок мас маркуванронічної продукції, другий - фермерський продукт, третій - продукт без знаків маркувания маркування органічної продукції на основі критеріїв оцінки.

й знак, органічна продукція, екологічні критерії, функціона-

Аннотация. Основные вопросы статьи посвящены экологической маркировке органической мясной продукции В то время, когда отношения между У краиной и странами Европейского Союза стали более интенсивными, сегмент ства органических продуктов сельского хозяйства, неотьемлемой частью которых является энергооптимизашия и курс на высокое качество и безопасность пищевой продукции, позволят Украине занять в будущем лидирующее место среди производителей органического. Учитывая контроль за такой продукцией со стороны иностранных органов серти- фикации, для обеспечения соответствия продукции указанным характеристикам, возникла потребность в объективных экспериментальных методах определения органичности товаров. В статье рассматривается один из самых важны этапов проддуры получения знака экологической маркировки органической продукции - разработка методики оце для проведения экспертизы, цели полном объеме характеризуют безопасность, биологическую активность и органичность мяса. В качестве исследуемых образцов мясной продукции было использовано свинину различных производителей. Первый образец имеет марровку органической продукции, второй - фермерский продукт, третий - продукт без знаков маркировки.

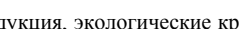
ерии, функциональные требования, безопасность продуктов, полный жизненный цикл продуцции.

\section{Вступ}

Екологічне маркування є одним 3 найбільш дієвих інструментів екологічної політики товаровикетки та декларації $є$ об'єктом розгляду стандартів 14040 , 1400, а саме труп ISO 14020 та ISO продукії̈ Знак еготогінного маркувания органіч-

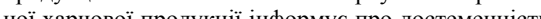
iii органінності, яжість, безпеку для споживачів навколиннього середовина та налас загальну характеристику екологічних аспектів продукту на усіх етапах повного життевого циклу. Тим самим екомаркування має на меті поступову диференціацію асортименту харчової продукції у межах одніеї категорії на користь органічних продуктів, що відповідають вимогам органічного та еко-ефективного виробництва, забезпечуючи зменши ік негативнона здоров'я людей та компоненти довкілля [1].

\section{Постановка проблеми}

Для отримання ліцензії на використання еколейблу підприємство зобов' язане пройти відповідну процедуру сертифікації. Одним 3 найважливіших етапів такої процедури $є$ розробка методики визначення органічності та подальша оцінка вироних критеріїв. Метою дослідження була розробка та обгрунтування критеріӥв оцінки продукту за поживача і навколишнього середовища.

Огляд літератури

На даний час у світі існують кілька десяткі сертифікаційних систем, які здийснюють оцінку відповідності продукції на основі базових
органічних стандартів Міжнародної федерації органічного сільськогосподарського руху (IFOAM) [2]. Контроль за іх діяльністю забезпенуен Міжнародним

В Украӥні діють 13 акредитованих органів яких 12 с представниками іноземних сертифікай них пілгрисмств та один національний укрӥнсьйй робника у міжнародному просторі. Екологічні етиго впливу сільського господарства і харчової галуз бу відповідно до розроблених науково обгрунтова- сертифікаційний орган. Кожен 3 них має власний код, що обов' язково вказується під знаком екологіфікашійні органи надають послуги присвосння знаку екологічного маркування продукції рослинництва, тваринництва, бджільництва, аквакультура продуктам переробки, дикорослим продуктам, засобам захисту рослин та добривам. Для кожно окремої заявленоі категорії товарів розроблюються

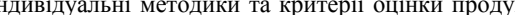
ціï, що передбачають подальше проведення еколо-

Річного аудиту, тестування, тощо.
Робота сертифікаційних органів базуеться на міжнародних, національних та приватних стандартах [4]. Ц Ці стандарти встановлюют правила ведення сільськогосподарського

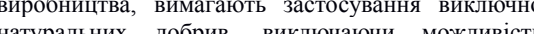
-

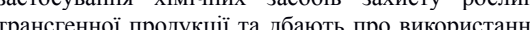
природних ресурсів, обмежуючи негативні вплив на довкілля протягом усіх етапів виробництва. В тваринництві основна увага приділяеться кормам умовам утримання тварин [5]. При виробиицте органічних продуктів переробки заборонено використовувати синтетичні ароматизатори, консерванти, харчові домішки та ін. Також до заборонених способів обробки готової продукци від прийоми, що знижують поживну цінність продукту, барвників та ароматизаторів.

\section{Основна частина}

Основним завданням методики визначення кції та визначення іiї впливу на довкілля. Якіст продукту є величиною інтегральною, що можо включати низку параметрів [6]. Обгрунтовано доцільність визначення критерію якості м' ясної продукції у розробленій методиці за середнім арифметичним значенням оцінок органолептичних показників якоспі, комплексних показників безпеки, комплексних показників нативності та показникі

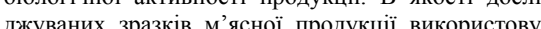
дали свинину різних виробників. верий зовуmec 
другий - представник фермерської продукції, тре- $\quad$ за температури $28^{\circ} \mathrm{C}$ і краплі суміші досліджували
тій - немаркований харчовий продукт. Органолептична оцінка наведених зразків бу- 10 хвилин та через 3 години. Критерієм оцінки безпечності дослідних зразків $\epsilon$ наявність рухливості екології харчових продуктів та виробництв, інфузорій через 3 години інкубації їх в водному та OHАХT. Оцінка здійснювалась відповідно до ацетоновому екстрактах зразків свинини, що забезДСТУ 7158:2010 «М'ясо. Свинина в тушах і півту- печує виявлення токсичних речовин полярної та шах. Технічні умови». Поверхня свіжого розрізу кожного зразку була волога, але не липка. М'ясний сік першого та другого зразків був прозорим, треM'яco на зрізі у трьох зразках мало світло-рожеде забарвлення. Запах свіжого для першого і другого зразку, у третього зразка апах був відсутній. Сало усіх трьох зразків мато білий колір з рожевим відтінком [7]. За результатами сенсорного аналізу найвищим балом, значенн якого складало 1 бал оцінено відразу два зразкиперший та другий, а третій отримав ошінку 0,5 балів.

Комплексні показники безпеки готової продукції визначаються за наявністю токсичних речови полярної та неполярної природи за допомогою методу біотестування - ефективного біологічного методу оцінки стану харчового продукту, забруднення якого токсичними речовинами може мати компллксний характер [8]. Надаючи мало інформадії про природу поллютантів, метод біотестування

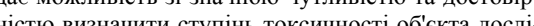
[9]. Для в разків було вілібрано бісіндикатор - культур Colpoda steinii, шо володіс високою універсалнісю [10]. Метод біотестування заснований на виділенні з дослідних зразків різних фракщій токсичних речовин за допомогою вілпов речовин за допомогою відпов іднии розчинників рою інфузорії колподи. В кожний 3 двох флаконів культурою колподи додавали по 2 мл поживного ередовища за 24 години до проведення досліджень, флакони закривали ватно-марлевими корками і витримували у термостаті за температури 26 - $28^{\circ} \mathrm{C}$. Безпосередньо перед дослідженням проводили контроль активності культури у висячій краплі під мікроскопом зі збільшенням у 8 разів [11]. Для визначення токсичності м' яса відбирались проби, 3 яких формувалась середня проба для пров се виої проби проводилось згідо «ГОСт 9792-73 Колбосные изделия и продукты из синины, баранины, говядины и мяса других видов убойных животных и птиц. Правила приемки и убойных животных и птиц. Правила приемки и
методы отбора проб». Наважку масою $20 \pm 0,1$ г кожного зразку вносили у колбу місткістю $250 \mathrm{~cm}^{3}$ та додавали $100 \mathrm{~cm}^{3}$ дистильованої води. Після ретельного перемішування та осідання важких фракцій отриманий екстракт фільтрували. Суспензію 3 ексцистованними інфузоріями з'єднували 3 рівним об'ємом досліджуваних зразків, піддавали інкубації 'яса рвинини наведено у таб̆лищі 1.

\section{Таблиця 1 - Шкала ощінки}

\begin{tabular}{|c|c|c|}
\hline $\begin{array}{c}\text { Токсич- } \\
\text { ність }\end{array}$ & Colpoda steinii & Бали \\
\hline Токсичний & $\begin{array}{c}\text { Загибель більшості колод на- } \\
\text { ступає впродовж 3 год }\end{array}$ & 0 \\
\hline $\begin{array}{c}\text { Слаботок- } \\
\text { сичний }\end{array}$ & $\begin{array}{c}\text { Вродовж 3 годин гине менше, } \\
\text { ніж 90 \% колпод }\end{array}$ & 0,5 \\
\hline $\begin{array}{c}\text { Нетоксич- } \\
\text { ний }\end{array}$ & $\begin{array}{c}\text { Впродовж 3 год всі колоди } \\
\text { залишаються рухливими }\end{array}$ & 1 \\
\hline
\end{tabular}

Результати біотестування за біосенсорами Colpoda steinii наведено в табл.2.

Таблиця 2 - Оцінка комплексних показників біосенсорами (Colpoda steinii)

\begin{tabular}{|c|c|c|c|}
\hline \multirow{2}{*}{$\begin{array}{l}\text { Номер } \\
\text { зразку }\end{array}$} & Водна проба & $\begin{array}{l}\text { Ацетонова } \\
\text { проба }\end{array}$ & \multirow{2}{*}{ Ба. } \\
\hline & \multicolumn{2}{|c|}{ Токсичність } & \\
\hline $\begin{array}{l}\text { Зра- } \\
\text { зок } \\
\text { №1 }\end{array}$ & \begin{tabular}{|c|} 
Всі колоди зали- \\
шилися рухливими \\
впродовж 3 год
\end{tabular} & \begin{tabular}{|r|} 
Всі колоди за- \\
лишилися рухли- \\
вими впродовж 3 \\
год
\end{tabular} & 1 \\
\hline $\begin{array}{l}\text { Зра- } \\
\text { зок } \\
\text { №2 }\end{array}$ & \begin{tabular}{|c|} 
Всі колоди зали- \\
шилися рухливими \\
впродовж 3 год
\end{tabular} & \begin{tabular}{|l|} 
Загибель $30 \%$ \\
колпод наступи- \\
ла впродовж 3 \\
год
\end{tabular} & 0 \\
\hline $\begin{array}{l}\text { Зра- } \\
\text { зок } \\
\text { №3 }\end{array}$ & \begin{tabular}{|c|} 
Всі колоди зали- \\
шилися рухливими \\
впродовж 3 год
\end{tabular} & \begin{tabular}{|l|} 
Загибель $55 \%$ \\
колпод наступи- \\
ла впродовж 3 \\
год
\end{tabular} & 0, \\
\hline
\end{tabular}

За результатами біотестування за біосенсорачний у трьох зразках. Результатом аналізу водної та 1 бал, що свідчить про його нетоксичність, другий анлізу водної проби та слаботоксиннии при дослідженні ацетонового вилучення, що свідчить про незначну концентрашію в них токсичних речовин

Комплексні показники нативності м'ясної продукції було визначено за допомогою сертифікованого методу біокристалізаціі, що широко використовується у країнах Свропейського Союзу. Це ми Colpoda steinii, вміст токсичних речовин незнанеполярної природи. кристалографічний метод, який базується на якісно-кількісному описі та інтерпретації кристалоутворення біосубстратів харчових продуктів та води у присутності солі $\mathrm{CuCl}_{2}[12]$. Результатом процесу біокристалізації є утворені біокристалограми, симетричність малюнку та розміру кристалів яких свідчать про природне походження даного виду продукції, який не зазнавав значного негативного впливу, тобто є показником натуральності досліджуваного зразку [13]. Несиметричність та дефорресивного впливу на харчовий продук (напричад, ресиво вль обо шо) або на захворювання тварин чи рослин, шо використовуволись як сировина дия готової продукції. Підготовка зразків м'яса свинини включала подрібнення до консистенції фаршу за допомогою подрібнення до консистенції фаршу за допомогою мягом 30 хвилин при кімнатній температурі, фільтрування, експозицію з $10 \%$ розчином $\mathrm{CuCl}_{2}$ та на-

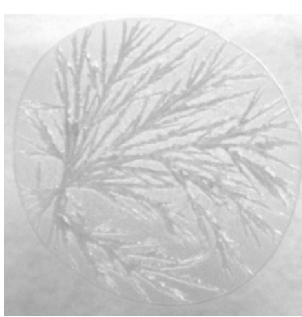

a)

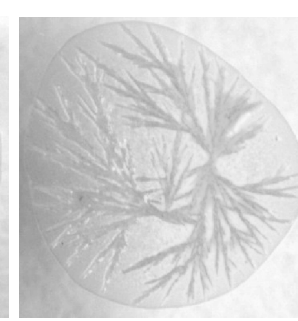

супним висушуванням краплі. Процес кристалізаціі біологічної речовини відбувався у термостаті за

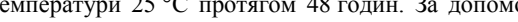

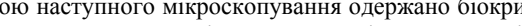
(1. Оцінка показник-

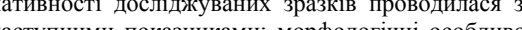
с ' си'

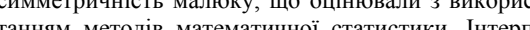
ретуючи переліені особливості, зрзии сөичин бер 75 , другий $-0,73$, третій $-0,48$ балів відповіно

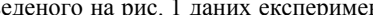
гальних досліджень, найбільш симетричною біокристалограмою характеризується перший та другий зразки, що свідчить про їх вищу ступінь нативності, яка визначається меншою часткою негативного ливу на продукт.

\section{Рис. 1. Біокристалограми м'яса свинини першого (a), другого (б) та третього зразків (в)}

Одними 3 найважливіших прооцесів, що забезпечують життедіяльність будь-якого організму, $\epsilon$ окисно-відновні реакціі. Енергія, що виділяється в результаті цих реакцій, витрачається на підтримання гомеостазу організму і регенерацію його клітин, тобто на абеспечення процесів життедіяль-

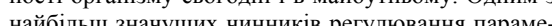
трів окисно-відновни реаній, ше протікарть в будь-якому рідкому середовищі, $\epsilon$ активність електронів або окислювально-вінновний потениіа тронів або окислювально-відновний потенціал нього середовища організму людини зазвичай зна100 мілівольт (мВ), що свідчить про факт, що внутрішнє середовище організму перебуває у відновлеганізму має ОВП близький до значення ОВП внутрішнього середовища організму людини, то електрична енергія клітинних мембран (життсва енергія організму) не витрачається на корекцію активност електронів і продукт негайно ж засвоюється, оскіметру [14]. Розбалансування механізмів регуляції ходиться в межах від мінус 200 до плюс ному стані. Якщо продукт, який надходить до ор- окисно-відновних процесів, що відбуваються в людському організмі, в даний час розглядається найважливіша причина виникнення багатьох хвороб, організм зношується, старіє, життево-важли органи втрачають свою функцію. Але ці негативн роцеси можуть бути сповільнені, якщо в організд 作

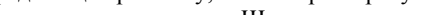
дуктів харчування, то окисно-відновні реакнії він. продуктів, багато 3 яких беруть безпосередню участь у формуванні найважливіших якісних показників. Особливого значення набувають ці системи в умовах зберігання продукту, де особлива увага приділяеться жировому компоненту продукції. Так

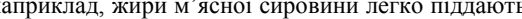
ся окиснювальним змінам, при цьому утворюютьея перекисні сполуки, що здатні взаємодіяти з сульф2дрильними групами низькомолекулярних тіолів . ОВП за допомогою ОВП-метру. Результати дослі- 
джень 3 визначення біологічної активності зразків органічним лейблом - 0,94 бали, фермерське м'ясо м'ясної біологічної активності наведено в табл. 3.

аблиця 3 - Оцінка значення окисно-відновного потенціалу зразків свинини

\begin{tabular}{l|l|l|} 
Назва зразку & Значення ОВП & Бали \\
\hline
\end{tabular}

Зразок №1 $\quad+110 \mathrm{mB}$

Зразок №2

\begin{tabular}{|c|}
\hline Бали \\
\hline 1 \\
\hline
\end{tabular}

$+145 \mathrm{MB}$
$+203 \mathrm{MB}$

свинини оцінено у 0,81 бал, оцінка м'яса свинини супермаркету складає 0,5 балів. Таким чином, за бальним рейтингом показників критерію якості продукції, найвищий ступінь якості та безпеки для споживача належить продукції, виробник якої має ліцензію сертифікованого акредитаційного органу на використання екологічного маркування.

\section{Висновки} джень, значення ОВП першого та другого зразку повідає вілов дазо харектеру $\mathrm{i}+145 \mathrm{MB}$, що відта оцінені у 1 бал, третій зразок відрізнясться під вишеним значеняя ОВП, шо становить $+203 \mathrm{MB}$ та оцінений у 0,5 балів, що свідчить про ймовірне порушення умов зберігання продукту.

За значеннями науково обгрунтованих показниками критерію якості продукції, найвищим балом характеризусться м'ясо свинини, шо марковане

Таким чином, науково обгрунтовано критерії методики екологічного маркування, що у необхідному обсязі та комплексно характеризують органічність, якість 1 безпечність м'ясних продуктів, а також найбільш ефективні методи їх оцінки.

Результати проведених досліджень свідчать про перспективність подальшого удосконалення методики екологічного маркування органічної про-

Список літератури:

Сергиенко О.И. Основные принцыпи и методологические аспекты экомаркирования пищевых продуктов
[Електронний ресурс] // Экономика и экологический менеджмент. ЭНЖ. 2010. - №2.- Режим доступу:

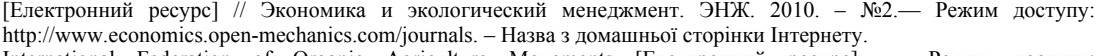

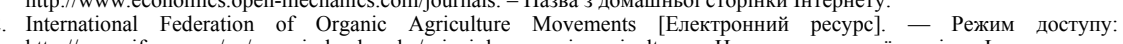
http://www.ifoam.org/en/organic-landmarks/principles-organic-agriculture. - Назва $з$ домашньоі сторінки Інтернету.
3. IOAS, Accreditation and Assessment [Електронний pecypc]. - Режим доступу: http://www.ioas.org/. - Назва 3

4. Сомашньої сторінки Інтернету. по результатам проведения Третьего молодежного экологического Конгресса «Северная пальмирау, - Спб

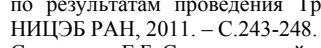

5. Селиванова Е.Б. Сравнительный анализ известных методов определения свежести мяса // Конференция-конкурс научноисследовательских работ молодых ученых и специалистов. - М,2007- С.115-117. кономічні та управлінські аспекти розвитку - Підприемств в харчовоі промисловості». - Одеса, ОНАХТ, 2013. - с.212-213. Seiivanova / / Proceedings of 54 International Congress of Meat Science and Technology. - Cape Town, South Africa, Борш // Міжвузівския кна оцінка рівня екологічної безпеки м'ясопереробних підприемств. / Р.І. Шевченко, Р.І. Одеса, ОНАХТ, 2012. С. -176 .

9. Крусір Г.В. Метод боотестирования как способ оценки критических контрольных точек / Г.В. Крусір,
I.П. Кондратенко, А.А. Думбрава // Сб. наукових праць молодих учених, аспірантів та студентів. - 2013, - т. 1. - С0. Виноходов Д.О. Биотестирование в птицеводстве и ветеринарии: Введение в биотестирование / Д.О. Виноходов,
Н.Л. Поляков // Ветеринария в птицеводстве. - 2003.-№5-6.-С. 41-46.

1. Виноходов Д. О. Определение микотоксинов методами биотестирования / Д.О. Виноходов, Н.Л. Поляков // Вете-

ринария в птицеводсть. - $2003 .-1$

of the Biocrystallisation Method [Текст] // Biodynamic Research

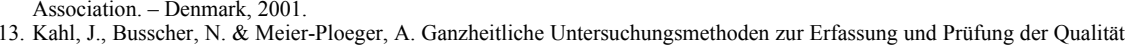

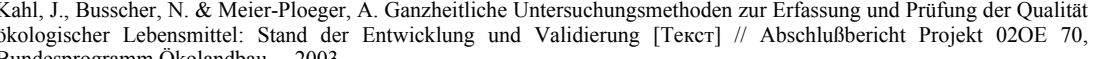

4. Колесниченко, П.Д. Влияние окислительно - восстановительного потенциала жидкостей, принимаемых внутрь на
морфофунцциональные особенности желудка, тонкого и толстого кишечника [Текст] / П.Д., Колесниченко, Н.В., Іобеева, О.Н. Цветикова // Новые информашионные технологии в мелишине, биологии, фармакологии и экологии: труды 20 Международной конференции и дискуссионного научного клуба - Ялта; Гурзуф, 2012. - С. 171-174. 15. ООщая химия: учеббик: для студентов мелицинских вузов [Текст] / А.В. Жолнин; под ред. акад. РАО В.А.
Попкова проф. А.В. Жолнина - Москва, ГЭОТАР-Мелия, 2012 - С. 399

УдК [504.06:005.934]:[631.147:664]

DOI

\section{РОЛОЛ}

Шевченко Р.І. кандидат технічних наук, доцент* E-mail: onaft-eko@yandex.ru Обухова А.С. магістр E-mail: agnessa.obukhova@mail.ru
*Кафедра екології харчових продуктів і виробництв Одеська національна академія харчових технологій

$$
\text { вул. Канатна, 112, м. Одеса, Україна, } 65039
$$

Анотація. У даній роботі, 3 точки зору термінології, проведено аналіз сучасних концепцій, які стосуються виробництва екологічно безпечної харчової продукції. 3 метою визначення поняття «екологічна безпека харчових продуктів» проаналізовано терміни, що єскладовими даного понятяя чи близькими до нього по значеннюо чи практиці вживання та тлумачення яки значено поняття «екологічна безпека харчових продуктів». Виявлено складові екологічної безпеки харчових продуктів, яи повною мірою впливають на неї та проведено їх дослідження з метою ідентифікації характерних аспектів та взаемних впливів Запропоноване визначення дас краще, порівняно 3 існуючими аналогінними поняттями, розуміння взаемозв' язків виробництва харчових продуктів, навколишнього середовища, виробничоі і соціальноі діяльності людини та і1 здоров'я та дозволяс спектру вілхолів з урахуванням впливу на навколишне середовише, включаючи людину. Дослідження скпадових поняття «екологіноі безпеки харчових продуктів» з метою ідентифікашї усіх аспектів повного життевого пиклу харчови ' та оцінка іх значимості дозволить запропонувати комплексний критерій оцінки екологічної безпеки харчових продуктів на ї Ключові слова: еколо

Аннотация. В данной работе с точки зрения терминологии проведен анализ современных концепший, касаюшихся производства экологически безопасной пищевой продукции. С целью определения понятия «экологическая безопасность пищевых продуктов» проанализированы определения, которые являются составляющими данного понятия или близкими к нему по знализа исполь ия дуктов). Выявлены составляющие экологической безопасности пищевых продуктов, которые в полной мере влияют на нее проведено их исследование с целью идентификации характерных аспектов и взаимных влияниий. Предложенное определени дает лучшее, по сравнению с существующими аналогичными понятиями, понимание взаимосвязей производства пищевых продуктов, окружающей среды, производственной и социальной деятельности человека и его здоровья и позволяет более «экологической безопасности пищевых продуктов» с целью идентификации всех аспектов полного жизненного цикла продуктов питания и оценка их значимости позволит предложить комплексный критерий оценки экологической безопасности пи-

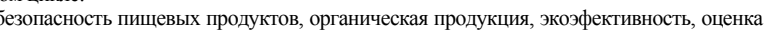
жизненного цикла

Вступ

Безпека харчової продукції і продовольчої сировини є однією $з$ вирішальних складових економічної та соціальної безпеки кожної держави й визначається спроможністю країни ефективно контролювати виробництво й ввезення безпечного та якісного продовольства на загальновизнаних у світ засадах. Разом 3 тим безпечність харчових продуктів дуже тісно пов' язана із безпечністю навколишнього середовища, залежачи від неї та в ході виробництва впливаючи на неї.

\section{Постановка проблеми}

На сьогоднішній день в спеціальній літератур чіткого та науково обгрунтованого визначення по-

Харчова наука і технологія няття «екологічна безпека харчових продуктів» (за Google, Yandex, Rambler та спеціалізованих журнасловосполучення можна зустріти доволі часто. В наукових публікаціях, як правило, словосполучен(еекологічна безпека харчових продуктів» використовуеться в контексті безпеки харчових продуктів (англ. - food safety) для здоров'я людини, ï феколгінності (англ. - environmental food) чи екоетективності (англ. - environmental efficiency). Частів» замінює поняття «екологічна безпека харчових виробництв», які не $є$ тотожними. результатами пошуку в пошукових системах 